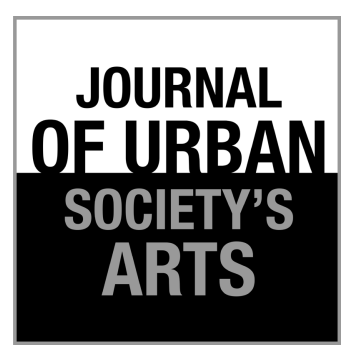

Volume 2 Nomor 1 , April 2015: 1-8

\section{Sungai sebagai Transmisi Ritual Urban Kesuburan melalui Pertunjukan Wayang Topeng}

\section{Robby Hidajat}

Program Studi Pendidikan Seni Tari dan Musik

Fakultas Sastra, Universitas Negeri Malang

E-mail: robby.hidajat.fs@um.ac.id; HP: 081234230924

\begin{abstract}
ABSTRAK
Sungai pada saat ini sudah mulai tidak mendapatkan perhatian masyarakat terutama dalam masyarakat urban, kebersihannya sudah tidak ada yang bersedia menjaga. Sampah dan cairan deterjen menjadi bahan yang mengotori kebersihan. Akibatnya air menjadi tidak lagi bersih, membawa bibit penyakit, dan mengakibatkan bencana banjir. Sungai bagi masyarakat desa di Malang pada waktu yang lampau memiliki arti penting, seperti tempat tertentu di antara bilik-bilik mandi yang disebut belik terdapat pundhen desa tempat roh nenek moyang bersemayam. Keyakinan masyarakat desa di Malang itu dikaji dengan teori strukturalisme-simbolis dengan menggunakan data wawancara dan observasi partisipatoris. Teknik analisis menggunakan interpretasi. Penemuannya adalah relasi yang kuat antara sungai, gunung, dan desa: (1) sungai adalah transmisi pemujaan kesuburan dari dewa gunung, (2) sungai menjadi manifestasi sib langgeng (cinta abadi), anugerah sing nguripi (yang menghidupi), dan (3) sungai diyakini sebagai wujud tirta pawitra sari; air kehidupan. Ritual urban pemujaan terhadap kesuburan adalah anugerah kehidupan yang diekspresikan melalui media seni pertunjukan Wayang Topeng.
\end{abstract}

Kata kunci: seni pertunjukan, ritual, wayang Topeng

\begin{abstract}
The River as a Transmission of Fertility Ritual through the Performing Arts Media of Wayang Topeng. Nowadays, the rivers are starting not to get any intention from our society; nobody is willing to keep them clean. Garbage and detergent liquid have become the contaminated materials for them. As a result for that matter, water has not been clean anymore, has carried germs, and has lead to floods. Long time ago, rivers for villagers in Malang had its significant value, like a certain place in the shower cubicles called 'belik', there was a 'pundhen desa' where ancestral spirits dwelled. The villagers' belief in Malang is analyzed with a symbolic - structuralism theory using the data of interviews and participatory observation. The interpretation is used as the analysis technique. The finding of the research is that there is a strong relation among rivers, mountains, and villages: (1) the river is the transmission of fertility worship of the mountain Gods, (2) the river becomes the manifestation of 'sih langgeng' which means the eternal love, the blessing of the almighty support 'sing nguripi', and (3) the river is believed to be a form of 'tirta pawitra sari; the water of life. The worship of fertility ritual is the blessing of life that is expressed through the performing arts media of Wayang topeng.
\end{abstract}

Keywords: performing arts, rituals, wayang topeng 


\section{Pendahuluan}

Penelitian ini dimaksudkan untuk menyimak eksistensi sungai karena dewasa ini, sungai-sungai sudah menjadi tempat pembuangan sampah rumah tangga, termasuk cairan deterjen sisa mencuci pakaian. Limbah industri rumahan yang mengolah berbagai bahan mentah menjadi makanan atau produksi yang menggunakan zat kimia langsung dibuang ke sungai. Sungai menjadi kehilangan fungsi mitos kesuburan karena ikan-ikan dan tanaman sepanjang sungai sudah tidak mampu lagi hidup secara sehat. Sampah plastik dan limbah rumah tangga langsung dilempar dari dapur-dapur. Seolah-olah air sebagai sarana yang sangat efisien untuk menghilangkan kotoran dengan cepat.

Seiring dengan menurunnya potensi sungai bagi kehidupan masyarakat, utamanya di berbagai kota, masyarakat desa di Malang ada yang masih meyakini bahwa sungai memiliki peran penting bagi masyarakat. Sungai menjadi tempat menggantungkan kehidupan. Tanah tempat masyarakat menumbuhkan berbagai tanaman sangat tergantung atas aliran sungai. Sungai Brantas mengaliri berbagai desa-desa di sebelah timur Malang dan Sungai Metro mengaliri desa-desa di sebelah Barat. Kedua sungai tersebut mengalir dari utara dan bermuara di laut selatan. Sungai-sungai itu sebelum mencapai muara digunakan untuk mengaliri sawah-sawah yang sangat luas. Kondisi ini yang membuat masyarakat sangat bersyukur atas aliran sungai-sungai di desa-desa mereka masing-masing.

Sungai Konto yang mengaliri desa-desa di daerah Ngantang, sepanjang lereng Gunung Kawi ke bagian selatan. Masyarakat desa-desa sepanjang Sungai Konto selalu diselenggarakan ritual bersih desa di tujuh babakan belik. Ritual itu selalu dilakukan dengan kurban seekor sapi jantan. Puncak acara diselenggarakan seni pertunjukan sebagai ungkapan rasa syukur. Masyarakat di Desa Pijiombo, Kecamatan Wonosari - Gunungkawi setiap tahun menyelenggarakan tradisi ritual bersih desa di belik Mbah Ngarijan. Puncak acara ritual digelar Wayang Topeng. Masyarakat Desa Kedungmangga dan Lowok, Kecamatan Pakisaji juga memiliki tradisi bersih desa di pundhen desa yang berada di tepi sungai. Desa dan sungai menjadi pasangan yang dianggap memiliki spirit kehidupan, sungai adalah eksistensi 'air' artinya hidup adalah roh, dan desa adalah eksistensi 'tanah' (bumi). Pasangan ini menyatukan suatu konsep tentang 'manunggal' merayakan urip (hidup).

Orang Jawa memahami urip (hidup) sebagaimana eksistensi bumi 'dunia.' Seperti menghayati kelahiran bayi; ari-ari sang bayi (merupakan bagian dari salah satu 'empat saudara kandung' yang menjaga individu, yaitu kakang kawah (air ketuban), terbumi (adhi ari-ari), getih (darah), dan puser (tali pusat) dikubur di dekat rumah. Penguburan itu dimaksudkan untuk menyusul 'kakaknya' sang air ketuban yang telah tumpah ke bumi lebih dahulu. Periuk tanah yang dilubangi alasnya diletakkan terbalik lalu dikubur. Hal ini mempunyai maksud untuk menyatukan semua perwujudan dengan tanah (Soetarno dalam Kusmayati, 2003:239).

Pemahaman tentang urip diyakini bermula dari kelahiran, hal itu juga diyakini adanya ruang kosmik, dimensi pemahaman yang lebih konkret, yaitu menempatkan pemahaman tentang kiblat (arah mata angin). Arah mata angin tempat kedudukan para dewa. Soedarsono (1999: 20) menjelaskan kedudukan para dewa sebagai berikut. (1) Wisnu di utara, (2) Sambu di timur laut, (3) Iswara di timur, (4) Mahesora di tenggara, (5) Rudra di barat daya, (7) Mahadewa di Barat, (8) Sengkara di Barat Laut, dan Siwa di tengah. Kiblat itu juga diyakini sebagai posisi letak dari desa, kaitannya dengan pundhen desa sebagai pusat pertumbuhan kehidupan. Para dewa diyakini bersemayam di puncak-puncak gunung yang dengan setiap menghimpun awan-awan menghasilkan anugerah dalam bentuk hujan. Hujan yang turun ke bumi adalah anugerah karena dapat menyuburkan tanah yang selesai dicangkup atau dibajak. Hujan tidak dipahami sebagai penyebab bencana yang mendatangkan banjir dan apabila terjadi banjir, masyarakat selalu mengintrospeksi diri. Terdapat suatu kemungkinan terjadinya suatu kesalahan yang sudah diperbuat oleh masyarakat yaitu kelalaian memerhatikan saluran air atau kemungkinan masyarakat kurang bersyukur terhadap rezeki yang diterima oleh masyarakat tersebut. Kurban atau sedekah sudah tidak menjadi semangat masyarakat 
untuk mampu melangsungkan kebersamaan hidup.

Posisi geografis Desa Kedungmangga menunjukkan sifat ruang kosmis dari jagad raya seperti yang digambarkan oleh Eliade (2002:40-41) yaitu suatu penciptaan dunia menjadi pola yang sempurna dari setiap gerakan manusia yang penuh daya cipta, apa pun tatarannya. Penghuni pemukiman desa selalu mengulangi kosmogonik dan esensi penciptaan dengan menyelenggarakan ritual bersih desa. Berdasarkan hal itu dimulai pemahaman yang lebih baik tentang mengapa manusia mengulangi penciptaan dunia dari titik pusat (pusar), yaitu letak pundhen desa. Di pusar tersebut masyarakat melakukan instrospeksi bahwa kehidupan itu bermula dari pusat, yaitu sumber air. Simbol dari tirta prawita sari, yaitu pertemuan antara benih laki-laki dan perempuan. Oleh karena itu, di berbagai persawahan di daerah Malang banyak ditemukan prasasti watu udel, simbol yoni (Suwardono, 2013:81).

Penciptaan jagad raya terhampar dari pusat dan terbentang ke empat penjuru mata angin, demikian pula desa dibangun di antara pembagian persimpangan jalan (perempatan). Desa-desa kuna di Malang seperti halnya di beberapa bagian di Asia. Pada saat desa baru dibangun maka penduduknya akan mencari persimpangan alami yaitu dua jalan berpotongan pada sudut yang benar. Tanah lapang yang dibuat di titik pusat merupakan imago mundi. Pembagian desa menjadi empat bagian yang secara sekilas menunjukkan pengelompokan serupa pada masyarakat - berkaitan dengan pembagian jagad raya menjadi empat horizon (Eliade, 2002:12-17)

Desa Kedungmangga menampakkan konsep imago mundi. Pada kaitan ini tampak memiliki kemiripan dengan letak geografis Kerajaan Kediri, Jenggala, Gegelang atau Ngurawan, dan Singasari. Persepsi tentang konstelasi ruang yang telah mengalami gejala anakronis dari fakta sejarah dan fakta lisan sehingga Sumardjo mencermati kosmologis Jawa pada masa kerajaan Jawa Timur abad XII - XIII. Di Jawa (Timur) waktu itu terdapat empat negara yang raja-rajanya masih saling bersaudara. Negara itu adalah Jenggala atau Kahuripan (utara), Daha atau Kediri (selatan), Singasari (timur), dan Gegelang atau Urawan (barat) (Sumardjo (2002: 249-250).
Konsep macapat yang mendasari eksistensi 'desa' juga terkait dengan mitos Panji. Konsep itu berkaitan dengan asal-usul Panji Asmarabangun sebagai titisan Arjuna dan Gunungsari sebagai titisan Samba, Sekartaji istri Panji Asmarabangun adalah titisan Subadara, dan Ragil Kuning titisan Haknyanawati.

Mitos Panji diuraikan dalam buku Tjerita Panji dalam Perbandingan tulisan Poerbatjaraka. Batara Guru telah memutuskan mengirimkan Arjuna dengan istrinya Subadra turun ke bumi. Samba dengan istrinya, Janawati juga akan dikirim ke bumi. Hal itu diharapkan bahwa Sang Hyang Tunggal dan Sang Hyang Wenang berkenan untuk turun ke bumi. Arjuna melihat Janawati berubah menjadi kembang seroja. Arjuna sendiri berubah menjadi serbuk bunga dan bersembunyi dalam kembang itu dan kemudian menjatuhkan diri di atas pangkuan raja Jenggala. Raja Daha, setelah mendengar laporan dari utusannya, lalu mengusulkan kepada permaisurinya untuk meminta kepada dewa-dewa, supaya Raja Daha diberi seorang anak perempuan yang cantik. Suami isteri itu lalu berdoa. Panji Asmarabangun identik dengan Arjuna. Sekartaji identik dengan Subadra. Perkawinan antara putra-putri Kerajaan Jenggala dan Kerajaan Kediri (Daha) menjadikan dua kerajaan tersebut menjadi satu. Perkawinan itu ialah perkawinan antara Arjuna dan Subadra dalam wujud Panji Asmarabangun dan Sekartaji atau Candrakirana dan perkawinan antara Gunungsari dan Ragil Kuning (Poerbatjaraka, 1968:3-4). Lakon Panji yang dipentaskan untuk menyemarakkan ritus bersih desa di Desa Kedungmangga, Lawak atau Pijiombo merupakan perayaan penyatuan urip (hidup). Prabu Lembu Amiluhur dari Jenggala dan Prabu Amijaya dari Dahasepakat menyatukan antara dua kerajaan. Penyatuan ini semata-mata untuk membuat rakyat dari dua kerajaan itu menikmati kesejahteraan dan keselamatan. Merayakan bersih desa di setiap belik di tepi sungai-sungai adalah niat untuk menjalin ikatan sosial. Penyembelihan kurban sapi di sepanjang sungai Konto merupakan spirit ikatan sosial. Penduduk desa yang merayakan ritual tersebut menerima berkah daging sapi kurban beserta organ sapi yang lain secara merata. Tradisi dari desa-desa yang lain adalah makan bersama 
yang disebut dengan kenduri. Sungai Konto seperti halnya sungai Metro yang mengaliri Desa Kedungmangga maka sungai ini diyakini sebagai simbol kehidupan dan penyelamantan yaitu mitos air amerta (Suwardono, 2013:81).

\section{Metode Kajian}

Kajian ini menggunakan pendekatan strukturalisme-simbolik, yaitu upaya penggabungan paradigma strukturalis dan kajian simbolik. Heddy Shri Ahimsa-Putra mengemukakannya sebagai berikut bahwa telaah tekstual dalam hal ini seni pertunjukan dan aspek simbolik yang disebut hermeneutik. Telaah tekstual dibedakan menjadi dua yaitu (a) telaah simbolik dan (b) telaah struktural. Kajian simbolik ataupun struktural pada dasarnya berusaha menafsirkan seni pertunjukan sebagai 'teks' sehingga dapat dibaca. Perbedaannya adalah bahwa dalam strukturalisme penafsiran ini dilakukan setelah karya seni dianalisis secara struktural terlebih dahulu, sedangkan dalam pendekatan simbolik tidak dilakukan (AhimsaPutra (Ed.), 2000:401-402).

Paradigma strukturalisme sebagai pendekatan diawali dari teori struktural fungsional. Teori ini di dalamnya menjelaskan perubahan-perubahan yang terjadi di masyarakat yaitu (a) masyarakat merupakan kesatuan utuh dalam kegiatan interaksi antar individu (prinsip holistik); (b) interaksi berlangsung timbal-balik yang menggunakan simbol-simbol tertentu; (c) masyarakat bersifat dinamis dalam kesatuannya dan (d) perubahan berlangsung secara gradual dan perlahan sebagai proses adaptasi dan penyesuaian (Ritzer, 2002:21).

Data yang digunakan dalam kajian ini adalah hasil wawancara dengan narasumber, yaitu Sumantri seorang ahli karawitan Malang; Suroso yang juga merupakan ketua perkumpulan Wayang Topeng Asmarabangun; Moch Dahlan seorang Kamituwa Desa Kedungmangga; dan M. Soleh Adi Pramono yaitu seorang dalang Wayang Topeng dari Tumpang. Data juga dikumpulkan melalui observasi dengan menyaksikan ritual bersih desa di Desa Kedungmangga, Lowok, dan Pijiombo serta mengamati kondisi sungai dan belik-belik di ketiga desa itu.

\section{Pundhen Desa sebagai Pusat}

Pundhen di Desa Pijiombo disebut Pundhen Mbah Ngarijan dan pundhen Desa Kedungmonggo disebut Pundhen Belik Kurung. Letak pundhen ada di tepi sungai. Tepat di bawah pundhen terdapat pancuran air yang disebut babakan. Sebuah tempat untuk membersihkan badan dengan cara mengambil air untuk memasak masyarakat desa. Kebiasaan masyarakat Desa Kedungmangga membersihkan diri di belik seakan-akan menjadi kebiasaan yang tidak dapat dihilangkan. Masyarakat desa Kedungmangga merasa lebih segar, lebih bergairah, dan lebih puas. Beberapa orang menceritakan bahwa mandi di sungai pada pagipagi buta terasa hangat dan segar. Kebiasaan masyarakat desa merupakan ritus sosial yang secara reguler dilakukan untuk menyucikan diri dari kotoran lahir dan batin manusia. Hal ini seperti dinyatakan Sucitra (2014:63) bahwa air adalah simbol kehidupan.

Desa Pijiombo, Kecamatan Wonosari memiliki tradisi bersih desa dengan cara memandikan dua buah topeng yaitu topeng patih (dua buah topeng yang di Desa Kedungmangga disebut dengan topeng bang-tih) di sebuah belik di areal Pundhen Mbah Ngarijan. Topeng itu setelah dipakai kemudian oleh penari dilanjutkan dengan membuat sesaji dan menari di pundhen desa. Hal ini menunjukkan adanya ritus siklus penyucian diri yaitu mengulangi siklus yang berhubungan dengan kelahiran. Harapan yang dimohon adalah menjadikan pribadi manusia dan juga desa lahir kembali, bersih, seperti kain yang belum ternoda.

Dalam Wayang Topeng juga dapat disimak tiga nilai bersifat sakral yang tampak dalam lakon sebagai berikut: Sekartaji adalah simbol rembulan yang letaknya di atas. Sinarnya selalu dinantinanti pada setiap siklus waktunya yaitu setiap bulan. Sekartaji adalah esensi dari feminin atau esensi dari 'ibu,' yaitu wanita yang menjadi sarana kesinambungan kehidupan. Esensi kehidupan dalam pertunjukan Wayang Topeng ditampakkan dalam tari pembuka yaitu Tari Beskalan Lanang atau Tari Bang-Tih. Adegan ini oleh Chattam A.R. disebut sebagai gambaran tentang asal usuling dumadi. Pada umumnya tari ini dikaitkan dengan sangkan 
paraning dumadi (asal usul dan pengembaraan manusia) yaitu pemahaman masyarakat Jawa tentang asal muasal kejadian manusia. Al-Gazali memahami asal usule dumadi sebagai berikut bahwa pada tingkat pertama atau bahan baku yang utama adalah turab (debu), kemudian ketika manusia disentuh air, maka disebut tin (lempung), dan pada saat lempung ini dilapuk zaman dengan sentuhan panas matahari sehingga menjadi kering dan mengeras, maka manusia kemudian disebut salsal (tanah liat) layaknya tembikar yang siap dibentuk. Panas matahari menimbulkan hawa udara dan dengan bukti-bukti syara' serta akal di atas dapat dikatakan bahwa bentuk Adam As. sedemikian sudah sah sebagai kawitan (awal), kemudian Allah menjadikan anak-keturunannya dari nuffah (sperma) yang keluar darinya dan ditangkap cepat oleh perempuan hingga terpisah dan menjadi sempurna. Hal itu terjadi dengan perjalanan waktu dan kesempurnaan penciptaan. Manusia mula-mula berupa sperma (nutfah), kemudian menggumpal menjadi gumpalan darah (alaqah), lalu berubah menjadi seonggok daging (mudgab), selanjutnya tumbuh tulang yang dibalut daging. Sperma yang keluar dari manusia berbentuk saripati seperti kupasan biji dari bijibijian, hanya saja sperma tersebut bersifat padat. Orang yang menyaksikan proses terjadinya buah pasti bisa meyakini hal ini. Buah delima misalnya keluar pertama dalam bentuk yang sangat kecil tetapi bentuk yang kecil itu kemudian dikuatkan secara alami dari luar hingga berbentuk sempurna dengan segala isi di dalamnya (Gazali, 1996:14).

Memerhatikan sejarah dumadi (asal usul manusia) adalah menjadi introspeksi adanya pundhen. Pundhen itu adalah pepundian, yaitu orang tua atau nenek moyang yang patut mendapatkan penghormatan. Pundhen merupakan asal segala hormat atau bakti dicurahkan sebagai bentuk rasa syukur sehingga tempat itu merupakan pusat dari pertumbuhan masyarakat.

\section{Ritual Asal Usul}

Asal-usuling dumadi merupakan pertanyaan yang sangat mendasar karena setiap perilaku orang Jawa selalu ingin mengetahui bibit kawit 'asal mula', satu wiji 'biji'. Oleh sebab itu, ritus kejadian desa yang sering disebut dengan bersih desa merupakan tindakan introspeksi yang di dalamnya terkandung rasa syukur dan harapan bagi masa depan. Kehidupan yang sementara ini senantiasa harus disyukuri. Oleh sebab itu, semua orang harus berusaha untuk mensyukuri. Rasa syukur itu dapat dilakukan dengan cara melakukan ritual suguh (puja). Introspeksi terhadap asal usul dumadi yang diarahkan kepada pundhen, juga diarahkan introspeksi pada weton (kelahiran). Hari kelahiran itu merupakan awal manusia ditentukan nasibnya. Memetri atau selamatan mengingat hadirnya pribadi adalah ungkapan rasa syukur. Salah satu sesaji yang disediakan adalah jenang abang atau bubur sengkala yang berfungsi sebagai penolak roh jahat atau tolak balak seperti yang ditampakkan pertama kali dalam pertunjukan Wayang Topeng, yaitu tarian pembuka yang disebut Tari Patih atau Tari Bang-Tih (berasal dari kata abang 'merah' dan putih 'putih'). Tarian ini disajikan dalam awal pertunjukan untuk menangkal roh-roh jahat yang mengganggu pemain dan penonton (Hidajat, 2011:57).

Tradisi membuka pertunjukan dengan tarian tidak hanya terdapat dalam Wayang Topeng tetapi juga dalam pertunjukan Wayang Kulit, Ludruk, Andong Tayub, atau Tayub. Wayang Topeng apabila dianggap sebagai pertunjukan yang paling tua maka dapat dipastikan bahwa tradisi menyajikan "tari" sebagai pembuka berasal dari Wayang Topeng yang merupakan bentuk kesadaran merayakan asal usul dan tolak balak.

Paham spiritual Jawa ditekuni oleh pemangku Wayang Topeng di Desa Kedungmangga. Di dalam kehidupan ini terdiri dari barang asal dan barang dumadi. Barang asal adalah suatu zat yang memiliki spirit hidup dan tidak akan mati atau rusak. Barang asal merupakan bibit kawit 'asal mula'. Oleh karena itu tradisi yang mendasarkan diri pada kebudayaan agraris seringkali melakukan upacara wiwit. Wiwit dari kata kawitan yang artinya awal atau asal (Beatty, 2001:223). Wiwit ini sudah diawali ketika orang menuai padi atau tebu. Masa itu dianggap sebuah masa yang diidentikkan dengan masa 'pertemuan' atau pernikahan. Dalam menandai siklus tersebut maka dilakukan upacara wiwit sewaktu akan mulai menanam padi. 
Dalam ritus wiwit selalu dibuat sesaji yang disebut pecok bakal yaitu sejumlah sesajen yang berupa: gedhang ayu setangkep 'pisang pilihan', jambe suruh, endog pitik, kelapa, gula setangkep, kaca pengilon 'cermin') dan serit 'sisir', wedak 'bedak', susur 'tembakau', lenga wangi 'minyak wangi', badeg beras ketan ireng 'arak tape ketan hitam', rokok, dan kembang telon (bunga kantil putih dan kuning, serta dilengkapi bunga kenanga).

Tampak beberapa ciri sesaji tersebut menunjukkan kesetangkepan, seperti gula, gedhang ayu setangkep, dan jambe suruh. Jambe suruh juga menunjukkan makna kesetangkepan. Anthony Reid menyatakan bahwa Jambe suruh menjadi sajian kehormatan untuk tamu serta sebagai perekat persahabatan. Sajian jambe suruh merupakan hakikat sopan-santun dan keramahtamahan dan arwah para leluhur juga harus diberi sesaji jambe suruh (sirih pinang) dalam setiap upacara ritus yang penting. Reid selanjutnya menghubungkan dengan sifat kesetangkupan (keterpaduan) sebagai berikut bahwa Jambe suruh merupakan simbol keterpaduan antara sifat laki-laki dan perempuan dalam hubungan seksual yang berupa dengan 'panas'-nya buah pinang diimbangi dengan 'dingin'-nya daun sirih.

Sesaji jambe suruh jelas mengarah pada perjodohan kesetangkepan yang diyakini akan menciptakan perwujdan baru. Keterkabulan harapan tersebut dianggap sebagai kondisi yang bersifat "subur". Simbolisasi harapan kesuburan terkait dengan endog pitik (telur ayam). Telur adalah bibit yaitu calon jasad hidup. Hal ini berarti sebuah harapan yang berkaitan dengan keturunan.

Menyimak beberapa simbol dari sesaji cok bakal tampak jelas terkait dengan tiga hal: (1) leluhur, (2) perjodohan, dan (3) harapan kesuburan. Tiga hal ini berkait dengan tema sentral dari lakon Panji. Konsep ini juga terkait dengan konsep triloka (tiga dunia) dunia bawah, tengah, dan atas (Hidajat, 2006:20). Konsep itu disebut barang asal (benda asali) yaitu tentang hakikat 'hidup.' Barang asal merupakan kesatuan dari spirit kehidupan dunia yang dipahami sebagai tiga domain tentang hidup, yaitu spirit tentang urip, Sing Nguripi, dan Sing Gawe Urip. Pengertian lain dari konsep triloka adalah adanya pemahaman tentang tiga alam; alam arwah, alam mitsal, dan alam ajsam (Mulyani, 2005:27).

Tiga unsur yang dikemukakan tersebut terkait dengan konsep Hinduisme yang dikenal dengan istilah 'Tri Murti' atau telu-teluning a-tunggal. Paduan dari tiga spirit tersebut menjadi kekuatan hidup yang mutlak yang dikenal dengan istilah Tan Kena Kinaya Ngapa, artinya zat itu tidak seperti apa-apa, jika halus tidak dapat dijimpit 'tan kena jinumput' dan apabila digelar akan memenuhi dunia 'yen digelar ngebeki jagad.' Analogi ini seperti Wayang Topeng ketika dipagelarkan yaitu apabila dipentaskan dapat memenuhi halaman sehingga rumah si empunya hajat tidak tampak, tetapi jika telah selesai semuanya dapat diringkas menjadi satu kotak yaitu kembali menjadi satu.

Secara konseptual adanya pemahaman lima unsur hidup terurai dalam lima zat yang disebut nur, rasa, nyowo, budi, dan nafsu. Lima zat hidup disebut adalah konsep tentang 'dumadi' (kejadian manusia). Lima unsur hidup tersebut menunjukkan pancer atau (pusat) atau lungguh, yaitu nyawa sehingga dari lima itu memiliki esensi empat dan lima yang memusat pada pusat (Beatty, 2001:238). Dalam kenyataan hidup yang tampak hanya satu yaitu "manusia". Di sini tampak adanya indikator tentang 'karakteristik' yaitu sifat kodrati. Hal ini dapat mengidentifikasi sejarah kodrat sebagai berikut: bahwa dari lima zat asali yang terdiri dari nur, rasa, nyawa, budi, dan nafsu akan menjadi suatu kesatuan ilahiah yang menunjukkan keberadaan bapa (ayah). Bapa dilambangkan dengan warna putih dan keberadaan biyung (ibu) yang dilambangkan dengan warna merah. Bapa dan biyung menunjukkan konsep dualitas. Konsep dualitas berhubungan dengan kaweruh kejawen sebagai berikut: bahwa kosmos terbagi menjadi dua yaitu pembagian secara vertikal tinggi dan rendah yang dikenal sebagai oposisi dualitas; kanan - kiri, besar - kecil, gelap - terang, dan sebagainya. Pandangan ini sering juga sering disebut monisme 'duality' yaitu pandangan tata alam yang serba dua namun satu. Pandangan dualisme religi asli Jawa ini sering disimbolkan bapa angkasa dan ibu pertiwi (langit dan bumi), padhang-peteng, lanang wadon, hidup dan mati, dan sebagainya (Soetarno, 2002: 24, Soetarno dalam Koesmayati (ed.). 2003: 237238, Mulyani, 2005:25). 
Paham kaweruh asli Jawa, ternyata telah mengalami transformasi dalam seni pertunjukan Jawa termasuk pemahaman dari pemangku Wayang Topeng di Desa Kedungmangga. Konsep duality hadir sebagai wujud simbolis Tari Patih atau Bangtih. Tarian ini mempunyai musik pemangku irama gerak yang disebut Beskalan. Beskalan mengandung pengertian cikal bakal atau bibit kawit. Hal ini menunjukkan bahwa Tari Bang-tih itu hakikatnya hadir sebagai 'sejarah kodrat,' yaitu asal-usul keberadaan manusia. Siklus tersebut yang dimulai dari wiwit hingga temanten atau temu, yaitu akhir dari Wayang Topeng, yaitu perjumpaan antara Panji Asmarabangun dan Dewi Sekartaji.

'Sejarah kodrat' jika ditelusur lebih jauh dapat diuraikan sebagai berikut: bahwa warna merah merupakan simbol 'laki-laki' yang turun dalam wujud wiji atau bibit, dan warna putih adalah lambang 'wanita' yang merupakan wadah (tempat untuk menumbuhkan wiji). Pertemuan antara merah putih merupakan indikator adanya 'kehidupan' atau awal dari adanya mobah mosik (dinamika). Di sini tercipta suatu ritme atau getaran dinamik yang khas menurut temperamen. Pemikiran ini terimplementasikan dalam bentuk gerakan gedrug gawang yaitu gerak menghentakkan kaki ke lantai pentas. Gerakan gedrug gawang ini dilakukan semua tokoh ketika akan memasuki arena pentas. Oleh karena itu dapat dipahami bahwa sebelum tokoh melintasi slambu atau tirai (tabir penyekat antara ruang ganti dan arena pentas) terlebih dahulu membunyikan gongseng yang dipasang di kaki kanan penari. Hal ini menandakan simbol ritme hidup dan setelah keluar akan melintasi slambu dengan cara di-piak yaitu dibuka dengan kedua tangan. Cara ini seperti bentuk tari Bali yang disebut mukah lawang (membuka pintu).

Gerak Gedrug Gawang - miak slambu mempresentasikan gerakan membuka pintu yang merupakan simbol kelahiran seorang bayi. Saat melakukan gerakan gedrug gawang - miak slambu merupakan kondisi yang bersifat liminalitas. Liminalitas menurut pemikiran Victor Turner adalah kondisi bersifat ambigu (tidak di sini dan juga tidak di sana). Liminalitas adalah dua ruang yang dibatasi oleh pintu tertutup. Liminalitas artinya ambang pintu. Subjek berada di tengah-tengah posisi yang ditandai oleh hukum, kebiasaan, perjanjian, dan upacara. Liminalitas dengan demikian dihubungkan dengan kematian, kelahiran, kemampuan tidak kelihatan, kegelapan, hutan belantara, dan gerhana matahari atau bulan (Winangun, 1990:37-40).

\section{Penutup}

Sungai merupakan simbol kehidupan karena air dipandang sebagai sumber untuk merayakan spirit urip (hidup). Suguh pundhen di belik-belik setiap aliran sungai menunjukkan eksistensi desa dan hasrat masyarakatnya yang menyadari tentang hidup sebagai persoalan yang sangat esensial. Hidup diyakini sebagai anugerah di dunia ini sehingga patut untuk dirayakan. Merayakan hidup adalah mensyukuri hakikat sih langgeng (cinta abadi). Pandangan ini diekspresikan melalui seni pertunjukan Wayang Topeng yang mempresentasikan lakon Panji. Kekuatan 'urip' (hidup) terletak pada tiga aspek yaitu raga, sukma, dan nyawa. Keseimbangan antara mikrokosmos dan makrokosmos disebut dengan istilah manunggal. Pemahaman ini merupakan pemahaman masyarakat pendukung Wayang Topeng Desa Kedungmangga, Pijiombo, dan Lowok tentang lakon Panji. Lakon Panji bukan berisi pertentangan antara kebaikan dan kejahatan dari tokoh-tokohnya namun lakon itu merupakan gambaran dinamika urip (hidup) yang harus diperjuangkan. Karimoen memahaminya dengan istilah mobah mosik (perubahan). Hakikatnya mobah-mosik itu terjadi karena adanya tritungal yaitu sing gawe urup, sing ngurupi, dan urup. Air membawa perubahan yang disebut mobah musik sebagai dinamika urip. Merayakan urip adalah bentuk rasa syukur dari usaha manusia untuk menyatukan diri dengan hakikat transendentalnya. Panji ketika telah mencapai kemanunggalan dengan istrinya, Dewi Sekartaji. Keduanya kembali ke Kerajaan Kahuripan yang mempunyai arti kembali pada urip (hidup) itu sendiri.

\section{Ucapan Terima Kasih}

Atas terselesaikannya hasil penelitian dan artikel ini, penulis mengucapkan terima kasih kepada: (1) Prof. Dr. Y. Sumandiyo Hadi sebagai 
promotor, (2) Prof. Dr. I Wayan Dana sebagai kopromotor, (3) Chattam AR. (almarhum) sebagai narasumber kunci, (4) seniman wayang topeng di berbagai desa di Malang, utamanya di Desa Kedungmangga.

\section{Kepustakaan}

Al-Gazali, 1996. Samudra Pemikiran Al-Gazali. Terj. Kamran As'ad Irsyady. Yogyakarta: Pustaka Sufi.

Ahimsa-Putra, Heddy Shri (Ed.). 2000. Ketika Orang Jawa Nyeni. Yogyakarta: Galang Press.

Beatty, Andrew. 2001. Variasi Agama Jawa di Jawa: Suatu Pendekatan Antropologi. Jakarta: Raja Grafindo Persada.

Eliade, Mircea. 2002. Mitos Gerakan Kembali yang Abadi. Yogyakarta: Ikon Teralitera.

Hidajat, Robby. 2006. "Relasi Simbolik Desa, Sungai, dan Pundhen dengan Pertunjukan Wayang Topeng Malang di Desa Kedungmangga, Karangpandan, Malang Jawa Timur" dalam Jurnal Kebudayaan Jawa Kejawen, Vol. 1, No. 2, Agustus 2006. . 2011. Wayang Topeng Malang: Struktur dan Simbolik Seni Pertunjukan Tradisional di Malang Jawa Timur. Malang: Gantar Gumelar.

Kusmayati, Hermien (Ed.). 2003. Kembang Setaman. Yogyakarta: BP ISI.

Mulyani, Hesti. 2005. "Piwulang Melalui Martabat Tujuh dalam Teks Serat Asmaralaya” dalam Jurnal Kebudayaan Jawa Kejawen, Vol. 1, No.1, September 2005

Poerbatjaraka. 1968. Tjerita Pandji dalam Perbandingan. Terj. Zuber Usman \& H.B. Jassin. Jakarta: Gunung Agung.

Ritzer, George. 2002. Sosiologi Ilmu Pengetahuan Berparadikma Ganda. Jakarta: Raja Grafindo Persada.

Soedarsono.1999. Wayang Wong.Yogyakarta: Gadjah Mada University Press.
Soetarno. 2002. "Pewayangan dalam Budaya Jawa" dalam Jurnal Dewa Ruci: Vol. 1, No. 1, April 2002.

Sucitra, I Gede Arya. 2014. "Dialektika Estetika Seni Rupa Kontemporer Bali Melalui Karya Upadana dan Valasara” dalam Jurnal of Urban Society's Arts. Vol. 14, No. 1 April 2014.

Sumardjo, Jakob. 2002. Arkeologi Budaya Indonesia. Yogyakarta: Qalam.

Suwardono. 2013. Tafsir Baru Kesejarahan Ken Angrok. Yogyakarta: Ombak.

Winangun, Y.W. Wartaya.1990. Masyarakat Bebas Struktur: Liminalitas dan Komunitas Menurut Victor Turner. Yogyakarta: Kanisius.

\section{Informan}

Sumantri (Malang, 6 maret 1954). Pengendang Karawitan Malang/Ketua sanggar Karawitan Lokabudaya. Urung-urung RT 01/RW 06 No. 1003, Bangkalan Krajan, Sukun, Malang. Chattam AR (Malang, 13 Oktober 1943). Penari/ Koreografer Tari Topeng Malang. Jl. Gading 14 a, Malang.

M. Soleh Adipramono (Malang, 1 Agustus 1951). Penari Topeng/Ketua Padepokan Seni Mangundharmo. Tulussayu, Tulusbesar, Tumpang, Malang.

Moch. Dhalan (Malang, 4 Mei 1959). Kamituwo Desa Kedungmangga. Jl. Parajurid Slamet, Kedungmangga, Pakisaji, Malang.

Suroso (Malang, 8 November 1971). Ketua Wayang Topeng Asmarabangun di Desa Kedungmangga. Jl. Parajurid Slamet, Kedungmangga, Pakisaji, Malang.

Sunari (Malang, tahun 1956). Pengrawit pada perkumpulan Wayang Topeng di Desa Kedungmangga. Jl. Raya Bendo, Kedungmangga, Pakisaji, Malang. Rasimen (68 tahun). Juru Kunci Punden Belik Kurung. Jln. Prajurit Slamet RT 17/RW 07, Kedungmangga, Pakisaji, Malang. 